costume they would wear a "tail" using grouse feathers in its construction. Their dancing would imitate the dance of the grouse.

Some of the details in Garry's report are a bit cofused, which can perhaps be explained by the fact that he reported something he saw several years ago. There are seven species of grouse in Saskatchewan, each with a distinctive mating dance.

The Ruffed Grouse dances alone, choosing as a rule a hollow log. Here he "drums" by rapidly beating the air with his wings. The Ruffed Grouse does not have the air sacs that some of the other grouse have, but does have a ruff of feathers from which it gets its name.

The Sharp-tailed Grouse usually dances in groups. They have air sacs which pump air in and out.

NOTE: The booklet "Sharp-tailed Grouse in Saskatchewan," which is reviewed on page 185 , can be obtained by writing:

Conservation and Information Service, Department of Natural Resources,

Regina, Saskatchewan.

\section{Small But Scary}

by Gerald Kreba, Rokeby, Sask.

One day Dad told me and my brother David to go down the power line and look for fence posts. The power line is a place with lots of bush near our place. As we were walking along we heard a loud screeching noise. We fell to the ground and listened. Then it came again. We decided to get a look at it. I thought it might be a bear, but. David said, "Don't be silly."

As we were sneaking along we saw a small bird sitting on a branch. It was smaller than a grouse. David said it was a small grouse but we decided differently when it looked at us. The bird's eyes were like marbles. In its mouth it held a struggling mouse. He was so busy with the mouse we got real close and had a good look at it. I thought it was a kind of owl. When we got home we looked at some pictures and found thait our scary friend was a Screech Owl.

NOTE: The Screech Owl is one of our smaller owls and is found in the southern part of the province. Its diet consists almost entirely of small rodents-mice, rats, ground squirrelsand is therefore considered beneficial.

\section{Wish}

By Helen Furtan and Elenor Konechny, White Rose School, Kegworth)

I wish:

I could sing like the meadowlark in the show.

I could pick a husibland like the Wilson's Phalarope to look after the children so I could go and visit the museum every day when I grow up.

I could run like an antelope.

I could tish like a pelican.

I had a windpipe as long as the Trumpeter Swan to call with.

I was as pretty as the Trumpeter Swan.

I had ears as long as the southern Jack rabbit so I could hear better.

We could all live in towns like the prairie dogs.

The boy sage hens' wouldn't strut around like that.

I had perfume like the sage brush.

I had long legs like the deer to jump with.

I was a porcupine with all those quills to stick somebody when I'm cross.

I was a skunk, so if boys come around me I could skunk them.

I was a buffalo to have a thick fur coat.

But I'm glad:

I'm not a snake having one meal in two weeks.

I'm not a cowbird eating ticks and lice off the buffalo.

I'm not a father Wilson's Phalarope and have to watch the baby birds alone.

That I went to the Saskaitchewan Museum.

EDITOR'S NOTE: This poem was inspired by a tour of the Museum made by the pupils of White Rose School. Guided tours are a regular part of the Museum's extension program. For information and application forms write to:

Extension Officer,

Sask Museum of Natural History, Regina, Saskatclıewan. 